\title{
Organizational Commitment of North Indian Journalists
}

\author{
Dr. Neha Miglani ${ }^{1}$
}

\begin{abstract}
For a journalist, credibility is explicably associated with his/her profession. The pressure of deadlines (at the organizational level) and of morality (from the reader's perspective) is immense. However, the work life of journalists is an area rarely discussed and so is their organizational commitment. Allegiance towards a journalists' organization may depend on several factors like impetus, monetary benefits, progress, opportunity to advance in career, fairness by superiors, among others. Organizational commitment is a barometer to test the faithfulness of an employee towards the organization. This in turn is instrumental in deciding his/her work output and efficiency. This paper was a rigorous exercise to get connected with practical problems of journalists and getting them to answer this structured questionnaire, with complete fairness and accuracy, was an arduous yet fruitful task. The study hence analyzes the organizational commitment of 81 journalists ( 56 males and 25 females) working in the print media section headquartered at Chandigarh (India) using a time-tested and structured questionnaire. The analysis was conducted viz-a-viz gender and monthly incomes of these journalists. The results of the study indicated significantly higher commitment levels among male journalists based in Chandigarh compared to their female counterparts (on affective and continuous organizational commitment dimensions individually). Commitment towards the organization had no impact across various income groups of journalists, which rules an important possibility of monthly salary (or monetary aspect) being a factor affecting commitment levels.
\end{abstract}

Key words:Journalist, Employees, Journalism

\section{Introduction}

In a fast pace world that demands excellence, productivity, better output and is ambitiously result oriented in every sphere, the human touch and concern for employees in most industries appears to be vanishing. Profitability and meeting the operational costs have become essential concerns of policy makers in organizations. The cut throat competition in every field has made these commercial factors inevitable too. The ambience provided at workplace assumes special significance for any employee irrespective of the industry he/she is working in. Better standards of living, a de-stressed environment, an individual's emotional needs and an overall balance in lifethese are some of the fundamental facets that require introspection in different sectors and industries considering the contemporary needs and times. Better standard of living and needs of an employee have unfortunately gone amiss due to hectic schedules in organizations which are caught up in shackles of sales, performance and results. Their importance is yet to percolate in the Indian work culture.

An individual is influenced by several factors at his/her workplace. From emotional needs, personal circumstances, cultural background, basics necessities in life, responsibilities other than work, expectations from his/her job,

\footnotetext{
1 Post-Doctoral Fellow (Fashion Journalism), U.I.F.T. E V.D., Panjab University, Chandigarh
}

personal and professional goals in life and several other factors influence the work orientation and productivity of an employee. It is the collective inputs of each employee in an organizational set up that eventually leads to team building and an overall desired result.

Among the most crucial organizations that have touched human population across all divides are those related to communication, media and entertainment systems. These media organizations deliver information that connects the smallest segment of the public to the most advanced, therefore providing a source of connectivity in the society. The role of media organizations in the Indian context is particularly significant due to the enormous diversity of culture, tradition and living standards of its people. Be it political, sports, religious, entertainment, glamour, informative or thoughtprovoking content- the Indian audience serves as a wide platform for media channels to interact, operate and transmit. Be it the conventional forms of media, or radio channels, print media, electronic channels or the internet- all these have touched the life of masses in some way or the other. The media organizations, through news and other mediums, significantly influence people and their perception about the world. They also give the audience or readers an insight into each event occurring in the neighbourhood and the far-off areas. At the onset of the day, right from which soap to use, to options of healthy breakfast and shaping perception about products, 
news, views- the media industry in India is catering to all these.

The most challenging task for any organization is to sustain a healthy model of functioning of its employees with progressive environment. Human resource professionals are dedicatedly appointed to streamline functioning of employees in organizations and take care of their needs. Often, it is the economics of journalism and news generation that dominates, and employee satisfaction takes a back seat in such a scenario.

Journalists in India typically enjoy a powerful status in the society due to the reach and influence of media on the masses. The ambit of media professionals includes reporters, subeditors, designers, photo-journalists and coordinators or editors in the news section.

\section{Employees and their Commitment Levels}

Commitment of journalists towards their organization could be influenced by several factors and one of the aspects is how the editor or the team leader deals with employees to keep them committed. To create an environment which is conducive for an employee, the leader's behaviour makes a crucial difference.

From the employee's perspective, the organizational commitment leads to career advancement and rewarding position as suggested by several researchers in human resource management field.

Commitment research has shown that people are more likely to develop higher levels of commitment when they can identify with the values and standards of the organization (Wiener, 1982).

An employee's commitment includes several aspects of how he/she perceives his/her organization and the goals. One of these aspects is the belief in the goals of his/her organization and the acceptance of this belief. Another is the amount of effort he/she puts in achieving that goal and third is the desire to retain association with the organization (Porters et al, 1974). From the perspective of the employer, to retain an employee also requires ensuring that the staff thinks and works in synchronization with the goals of organization.

\section{Journalists and Work Place Issues}

One of the key works on media professionals is related to work place issues and problems for journalists. Among the recent research works in this direction include those by McQuail (2000) as well as Preston (2009) who focused on the work life of journalists. Shoemaker \& Reese (1996)gave a model on levels of influence, which elaborates how news making is influenced at various levels (Hanitzsch\&Mellado, 2011).

The International Federation of Journalists (IFJ) which is a global federation of journalists' trade union published a report in collaboration with WageIndicator, a partner of Amsterdam Institute of Advance Labor Studies, University of Amsterdam. This report- Gender Pay Gap in Journalism(2013) mentions that women journalists continue to face discrimination in terms of wages and benefits.

Besides gender studies, researchers have also probed the connection of the market forces with the newsroom and the culture within the media organizations. Plasser (2005) finds that the media organizations too are driven by profit motive and in the age of commercial environment, cutbacks in newsroom and staff to ensure profitability in organizations is acceptable. Cutting costs is also a part of this profit driven system.

The commercial environment and profit oriented media organizations also affects the content and the profession itself (Plasser, 2005). The profession is focused on ratings and circulations and due to this motive, the obvious drift is towards attracting more audience or readership through suitable editorial content to ensure there is no loss of circulation.

Not only the media organizations, but even the journalists are affected by these market forces. Some researchers have worked in this direction to find what print journalists think of the news business and how it affects the opinionated journalism (Kuhn \&Neveu, 2002). When media professionals use their own personal judgment, it has no concrete or direct evidence.

Prior to these researchers, Blumer\& Kavanagh (1999) found that journalism was constantly and increasingly under the pressure of matching the goals of media organization. The style of journalism had to be in synchronization with media goals of the company.

\section{Issues with the Indian Media}

Among several other issues that have become crucial for the regulatory bodies to monitor and introspect, here are a few issues that confront Indian journalists and Indian media organizations. Job Security, wages, media bias have been among the top quoted concerns of several regulatory bodies and neutral agencies who have been closely studying the Indian media. 


\subsubsection{Job Security of Media Professionals- Press Council of India's Report (2010)}

The statutory body of press- the Press Council of India (PCI) highlighted in its report on 'Paid News' issued in 2010 the concern of job security among journalists citing that it is mandatory to ensure reliability of news. This report, issued on July 3, 2009, stressed on the importance of having media professionals including correspondents on regular jobs to make sure that malpractices can be controlled in the media sector and fairness ensured. It also raised a concern on the role of correspondents reduced to agents for collection of advertisement in certain newspapers and organizations.

\section{Wages of Journalists- Justice Majithia Commission Recommendations (2010)}

Wage fixation process in India was initiated around 1958 and other countries in South Asia followed suit. Despite this, wages of media professionals in present times remains ambiguous and ironical (International Federation of Journalists, 2012). On October 25, 2011 the Union Cabinet of the Government of India officially gave a go ahead to the recommendations of G.R. Majithia Wage Board for journalists and nonjournalists, the report for which was submitted in December 2010 to the Ministry of Labour and Employment. These recommendations were the basis of increased wages for newspaper workers. A key problematic area for fixing wages of journalists and non-journalists in media industry was assessment of industry's capacity to pay its employees. In July 2011, the Supreme Court declined to stay the implementation of this wage board, indicating that media houses must increase wages. Small newspapers like the Assam Tribune and Maghyamam, have already implemented the wage board recommendations citing an example for the industry. In 2014, the Supreme Court of India upheld its decision of swift implementation of wage board recommendations. There are a host of newspapers and media groups who have implemented the wage board recommendations, but with aberrations and anomalies. Several incidents, which went unreported, claim that journalists were transferred from their original station to other tougher areas in a bid to pressurize them to leave the 'permanent jobs' to evade implementation of wage board recommended revised salaries. However, the execution is awaited at the ground level by several other media houses.

\section{Theoretical Framework of the Study}

There is a serious dearth of theories concerning media houses, media newsrooms or media professionals or even commitment levels of journalists. Here however is an attempt to link organizational commitment of other employees to this study. The media professionals and journalists are eventually employees in an organizational setup and hence the need to study other sectors for organizational commitment.

Cheng et al. (2002) proposed a long-term commitment model which takes into consideration long term changes in the organization. This model considers those components that stimulate commitment level of employee and management to satisfy stakeholders. The satisfaction of employee and management resulting from favorable performance in the organization will ensure the commitment of the employees further to the organization. The researchers found this interdependence of commitment and satisfaction of employees and it was beneficial for the organization.

A host of researchers have concluded that affective dimension of commitment, that is- employee's willingness to stay in the organization because he wants to, depends on generally positive perception of management and organization, like organizational support (Rhoades \&Eisenberger, 2002). Much of this positive attitude is also to do with trust in the management (Pearce, 2003). Commitment to the organization is also triggered by climate at work and friendly practices (Guest, 2003).

Meyer et al. (2002) went further to find relation between three forms of commitment mentioned in the three-component model with- affective, normative and continuous commitment as its dimensions. The researchers found that these three forms of commitment are related to each other and distinguishable. These forms of commitment are related to job satisfaction, job involvement and occupational commitment. Affective commitment was found to have strongest and most favorable correlation with outcomes related to organization and employee like attendance, performance, stress and work-family conflict. Even as normative commitment was also associated with desirable outcomes, although not as much as affective commitment. Continuous commitment was negatively related to outcomes or productivity of the organization.

Meyer \&Herscovitch (2001) identified that employees can develop multiple work-related commitments and that commitment was a multidimensional construct. There is a considerable amount of disagreement on commitment itself among researchers and literary definitions, on how 
commitment affects behavior or how it is developed. Many scholars have opined that commitment should have a basic and essential definition and outline regardless of which context it is used in.

Another interesting study was done to further research on three-dimensional model of commitment. Finegan (2000) studied the influence of personal and organizational values on affective, normative and continuous commitment. The study revealed that affective commitment was highest when there was resemblance between individual's goal and those of organization. This was not the case with normative commitment.

This current study on commitment of journalists primarily observes and works on the theory propounded by Meyer et al. (2002) who gave the relation between affective, normative and continuous commitment dimensions.

\section{Review of Literature}

Jaramillo et al. (2005) studied the commitment of sales and non-sales employees and opined that the relationship of organizational commitment and job performance was positive for sales employees. There was a strong correlation between organizational commitment and job performance for collectivist compared to individualistic cultures.

More research on commitment was done by Tellefsen\& Thomas (2005) explored the role of individual in an organization and identified six qualifications to each type of commitment. They explored potential for business service customers to form separate bonds of commitment with service firm and representative.

Another study by Riketta\& Dick (2005) suggested that the workgroup and organization are common foci of employee attachment, including identification and commitment. They empirically investigated impact of attachment to work attitude and behavior. They concluded that work group attachment is stronger than organizational commitment.

Dawley et al. (2005) studied that multidimensional nature of organizational commitment using Meyer \& Allen (1997) scale. Data was gathered from 616 respondents in 36 states and effect of organizational commitment was measured on various roles of board members. The results show that normative, affective and continuous commitments are all based on low alternatives. These components of commitment had positive effect on the role of board members.
Kim et al. (2005) conducted a study to evaluate employee service orientation and employee's job satisfaction, organizational commitment and the intention of employees to leave. Results of this study indicated that customer focus of employee was negatively associated with job satisfaction and positively related to organizational commitment. Job satisfaction was also found positively associated with organizational commitment and negatively related to employee's intention of leaving the organization.

Impact of organizational commitment on certain parameters was studied by Vandenberghe et al. (2004) and it was found that it has indirect effect on turnover through an intent to quit, it was partially connected to supervisor's functioning and nature of work group too. The researchers found that organizational commitment had a direct impact on job performance through commitment to supervisor.

Kondratuk et al. (2004) evaluated the relationship between career mobility history and recent internal and external job change on organizational commitment using Meyer \& Allen (1991) scale. The number of external job moves in a career of employee or the career mobility history was negatively related to normative commitment but not to affective and continuous commitment. It was found that affective and continuous commitment was lower for external movers compared to non-movers prior to a move.

\section{Studies Related to Organizational Commitment in the Indian Perspective}

A study on effect of interaction between manager's quest for innovation and budget emphasis on the organizational commitment of employees was conducted bySubramaniam\& Mia (2003). Results from the study indicated that when low budget was adopted, it led to high organizational commitment particularly when managers' quest for innovation was high. This was not true when managers' quest for innovation was low.

Sinha et al. (2002) evaluatedthe relationship between organizational commitment, self-efficacy and perceived psychological barriers to technological changes in the organization. The researchers considered a sample of 167 male managers and found that organizational commitment was positively related to their age, length of service and self-efficacy. Commitment to the organization was negatively related to psychological barriers in context of technological change.

Khan \& Mishra (2002) studied the correlation between need satisfaction of employees and their 
organizational commitment. They considered a sample of 150 rail engine drivers using Indian adaptation of Porter's Need Satisfaction scale by Khan \& Mishra (2001) and organizational commitment scale by Allen \& Meyer (1993). The organizational commitment scale measured the affective, normative and continuous commitment whole need satisfaction scale measured compensation, social/common, autonomy/egoism, esteem and selfaccomplishment.

\section{Rationale of the Study}

The rationale of the study is to conduct an indepth analysis of organizational commitment of journalists and to compare the commitment levels of journalists vis-à-vis their gender and monthly income. The study aims to find whether factors like gender and income have a significant impact on organizational commitment of a journalist.

\section{Objectives of the Study}

Based on the research gaps from the review of literature, following are the key objectives of this study:

1. To determine the Organizational Commitment among journalists towards the organization vis-à-vis gender.

2. To determine the Organizational Commitment among journalists towards the organization vis-à-vis monthly income.

\section{Research Design}

Descriptive research is used when the phenomenon is well structured and understood. This kind of research requires a systematic and critical approach to get information and analyze it.

Sample and Methodology: The study hence analyzes the organizational commitment of 81 journalists (56 males and 25 females) working in the print media section headquartered at Chandigarh (India). These are accredited journalists recognized by the state as full-time employees of media organizations.

Statistical Tools Used: SPSS version 17.0 (SPSS Inc., Chicago, IL, USA) was used to carry out the statistical analysis, descriptive statistics i.e. mean, and SD, Independent t-test and F-test were the main tools of analysis. T-test and F-test were the mains tools used to see mean difference among gender and income levels of accredited journalists for organization commitment and its three dimensions.

Operational Definition: Organizational commitmentis regarded as a positive employee response to progressive employment practices, such as team working, training provision or employee share schemes. It determines whether the employee will stay with the organization or not. Perceived Organizational commitment of journalists has been measured in this study.

\section{Research Hypotheses:}

Ho1: There is no significant difference in the Organizational Commitment among journalists based on gender.

Ho2: There is no significant difference in the Organizational Commitment among journalists based on monthly income.

Research Instruments Used for Data Collection: Organizational Commitment Scale by Meyer, Allen \& Smith (1993). This five-point scale measured three themes through 18 items/questions classified under three heads:

- Affective Commitment i.e. extent to which employees remains with the organization because they want to.

- Continuance commitment i.e. extent to which employees remains with the organization because they need to.

- Normative commitment i.e. extent to which employees remains with the organization because they feel they ought to do so.

\section{Results and Discussions}

Table1: Mean, SD and t-value between male and female journalists for organizational commitment

\begin{tabular}{|c|c|c|c|c|c|c|c|}
\hline & \multicolumn{2}{|c|}{$\begin{array}{c}\text { Male } \\
(\mathrm{n}=56)\end{array}$} & \multicolumn{2}{c|}{$\begin{array}{c}\text { Female } \\
(\mathrm{n}=25)\end{array}$} & t-value & $\mathrm{df}$ & $\begin{array}{c}\mathrm{p} \\
\text { value }\end{array}$ \\
\hline & Mean & SD & Mean & SD & & & \\
\hline Affective & 20.38 & 3.35 & 15.84 & 1.89 & 6.32 & 79 & $0.00^{* *}$ \\
\hline Continuous & 18.07 & 3.16 & 17.48 & 2.79 & 0.81 & 79 & 0.42 \\
\hline Normative & 20.96 & 3.84 & 17.44 & 4.71 & 3.55 & 79 & $0.00^{* *}$ \\
\hline $\begin{array}{c}\text { Organizational } \\
\text { commitment }\end{array}$ & 59.41 & 8.49 & 50.76 & 5.40 & 4.68 & 79 & $0.00^{* *}$ \\
\hline
\end{tabular}

Table 1 revealed that journalists showed significant difference on affective, normative commitment and total organizational commitment at 0.01 level of significance and nonsignificant mean difference was observed for normative organization at 0.05 level of significance. From mean value, it was clear that male's media professional show more significance on Affection commitment ( $M=20.38)$, Continuous organizational commitment $(\mathrm{M}=20.96)$ and total organizational commitment $(\mathrm{M}=59.42)$ as compared to femalejournalists of Chandigarh. Mean difference between males and femalesisin Figure1. 
Figure1: Mean comparison of organizational commitment between male and female journalists

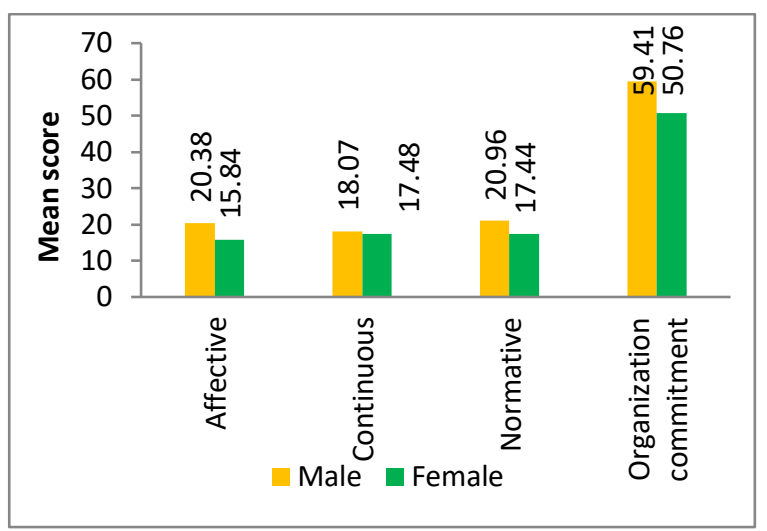

Table 2: Mean, SD and F value between among income level for organization commitment

\begin{tabular}{|c|c|c|c|c|c|c|c|c|}
\hline & \multicolumn{2}{|c|}{$\begin{array}{c}\text { Less than } \\
\text { Rs20,000(n=40 } \\
\end{array}$} & \begin{tabular}{c} 
Mean \\
\cline { 2 - 8 }
\end{tabular} & $\begin{array}{c}\text { SD } 20001- \\
40000 \\
(\mathrm{n}=34)\end{array}$ & $\begin{array}{c}\text { Mea } \\
\mathrm{n}\end{array}$ & $\begin{array}{c}\text { SD } \\
1,00,000 \\
(\mathrm{n}=7)\end{array}$ & $\begin{array}{c}\text { Mea } \\
\mathrm{n}\end{array}$ & $\mathrm{F}$ \\
value & P value \\
\hline Affective & 19.18 & 3.95 & 18.47 & $\begin{array}{c}3.4 \\
6\end{array}$ & 20.29 & $\begin{array}{c}2.2 \\
9\end{array}$ & 0.84 & 0.44 \\
\hline Continuous & 17.70 & 2.57 & 18.32 & $\begin{array}{c}3.1 \\
2\end{array}$ & 16.86 & $\begin{array}{c}4.9 \\
1\end{array}$ & 0.82 & 0.44 \\
\hline Normative & 20.60 & 4.30 & 19.65 & $\begin{array}{c}4.4 \\
3\end{array}$ & 16.86 & $\begin{array}{c}4.1 \\
0\end{array}$ & 2.30 & 0.11 \\
\hline $\begin{array}{c}\text { Organizationa } \\
\text { 1 commitment }\end{array}$ & 57.48 & 7.95 & 56.44 & $\begin{array}{c}9.3 \\
1\end{array}$ & 54.00 & $\begin{array}{c}9.6 \\
8\end{array}$ & 0.51 & 0.60 \\
\hline
\end{tabular}

Table2 revealed that journalists showed nonsignifican tmean difference on Affective, continuous, Normative and organizational commitment difference among income levels for organization and its dimension at 0.05 level of significance. Therefore, it can be said that all income levels of journalists show equal perception on organizational commitment and its dimension. Mean comparison of different levels of incomes for organization and its dimension is shown in Figure2.

Figure2: Mean comparison of journalists among different levels of income for organizational commitment

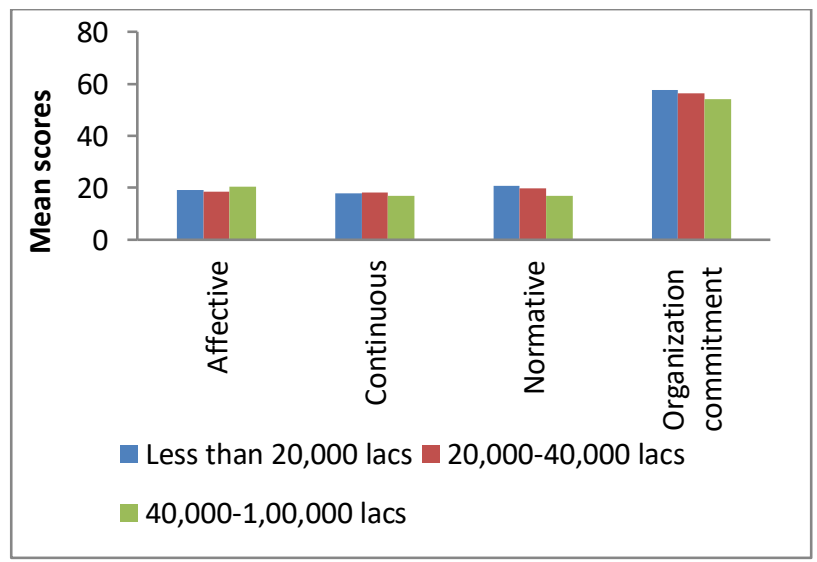

\section{Conclusion}

Malejournalistsof Chandigarh showed more significance on affective, continuous and total organizational commitment dimensions than females, whereas for different income levels journalistsshowednon-significant difference on organizational commitment and its dimensions.

- Organizational Commitment of male journalists was higher for their organization than for females. Certain reasons attributed to this finding include family responsibilities, nature of tasks designated in the organization, work culture in the organizational set-up among others. Hence, the above hypothesis is accepted in terms of gender of respondents.

- Organizational commitment among journalists is not affected by the monthly incomes. This could be attributed to the stability that the profession or organization has brought to their personal, social, economic position and loosing this stability might appear to be a loss to them.Hence, the above hypothesis is rejected in terms of monthly income of respondents.

The results of the study indicated significantly higher commitment levels among male journalists based in Chandigarh compared to their female counterparts (on affective and continuous organizational commitment dimensions individually). Commitment towards the organization had no impact across various income groups of journalists, which rules an important possibility of monthly salary (or monetary aspect) being a factor affecting commitment levels.

In the context of media industry in India, certain parameters specific to the industry need to be identified which affect employee's organizational commitment and whether commitment had an impact on performance of the media's circulation or popularity. Cohen (1998) had pointed out that when employees lacked professional commitment, it can be assumed that they intend to leave.

\section{Implications of the Results and Findings vis-à- vis Indian Media Industry}

There is a need to look at the newsroom culture and employees commitment (its reasons and indepth understanding of what leads to such results). Less relative organizational commitment among females could be a serious outcome of work culture, load sanctioned or duties allocated to a journalist. With scores of examples of fearless female journalists going on crucial assignments 
and sacrificing their lives for a good informative scoop or a good photograph (like their male counterparts), this could cast a serious remark on the gender disparity in the profession. The analysis and outcome are not just limited to 'usual' gender discussions but goes a step deeper to find the nature of this profession called 'journalism'. The second result from this paper about organizational commitment not being dependent on monthly incomes, is another significant finding to evaluate 'journalism' as a profession. It goes a step ahead and is in contradiction with qualitative studies conducted by the researcher. Detailed interviews of journalists from interiors of states like Uttar Pradesh reveals the apathetic condition of journalists and stringers, who are forced to work on meagre salaries. The study can prove a small yet noteworthy step in appraising and understanding the profession of journalism.

\section{References}

Allen, N. J., \& Meyer, J. P. (1990). The measurement and antecedents of affective, continuance and normative commitment to the organization. Journal of Occupational Psychology, 63 (1), 1-18.

Allen, N. J., \& Meyer, J. P. (1996). Affective, continuance, and normative commitment to the organization: An examination of construct validity. Journal of Vocational Behavior, 49 (3), 252-276.

Blumler, J.G. \& Kavanagh, D. (1999). The third age of political communication: influences and features, Political Communication, 16 (3), 209230.

Cheng, Y. \& Stockdale, M. S. 2003. The validity of the three-component model of organizational commitment in a Chinese context.Journal of Vocational Behaviour, 62, 456-489.

Cohen, A. (1998). An examination of the relationship between work commitment and work outcomes among hospital nurses. Scandinavian Journal of Management, 14 (1), 117.

Dawley, D. D., Stephens, R. D., \& Stephens, D. B. (2005). Dimensionality of organizational commitment in volunteer workers: Chamber of commerce board members and role fulfillment. Journal of Vocational Behaviour, 67 (3), 511-525.

Finegan, J.F., (2000). The impact of personorganisational values on organizational commitment. Journal of Occupational and Organisational Psychology, 3 (2), 149-69.
Guest, D. E., Michie, J., Conway, N., \& Sheehan, M. (2003). Human resource management and corporate performance in UK. British Journal of Industrial Relations , 41 (2), 291-314.

Hanitzsch, T., \& Mellado, C. (2011). What shapes the news around the World? How journalists in eighteen countries perceive influences on their work. The International Journal of Press/Politics , 16 (3), 404-426.

Hanitzsch, T., Hanusch, F., Mellado, C., Anikina, M., Berganza, R., \& Cangoz, I. (2010). Mapping journalism cultures across nations. Journalism Studies Routledge , 12 (3), 273-293.

International Federation of Journalists (IFJ). (2012). New Frontiers, New Struggles: Press Freedom in South Asia 2011-2012. Retrieved May 13, 2013, from

http://asiapacific.ifj.org/assets/docs/047/025/31186 2f-80f5b19.pdf

International Federation of Journalists (IFJ). (2013). Gender Pay Gap in Journalism.WageIndicator\&Amsteradam Institute of Advanec Labor Studies, University of Amsterdam. Retrieved October 10, 2013, from http:/www.paycheck.in/files/gender-paygap-oct-2012-1.

Jaramilloa, F., Mulkib, J. P., \& Marshallc, G. W. (2005). A meta-analysis of the relationship between organizational commitment and salesperson job performance: 25 years of research. Journal of Business Research, 58, 705714.

Khan, S.M., \& Mishra, P.C. (2002). Tips of bang on avoidance behaviour-An experience with railway officers.Journal of Indian Academy of Applied Psychology, 28 (1), 131-138.

Kim, Y. G., Bock, G.W., Zmud, R. W., \& Lee, J.N. (2005). Behavioral intention formation in knowledge sharing: Examining the roles of extrinsic motivators, social-psychological forces, and organizational climate. MIS Quarterly , 29 (1), 87-111.

Kuhn, R., \& Neveu, E. (2002). Political Journalism: New Challenges, New Practices. London: Routledge.

Kim, Y. G., Bock, G.W., Zmud, R. W., \& Lee, J.N. (2005). Behavioral intention formation in knowledge sharing: Examining the roles of extrinsic motivators, social-psychological forces, and organizational climate. MIS Quarterly, 29 (1), 87-111.

Kuhn, R., \& Neveu, E. (2002). Political Journalism: New Challenges, New Practices. London: Routledge. 
Kondratuk, T.B., Hausdorf, P.A., Korabik, K. \& Rosin, H.M. (2004). Linking career mobility with corporate loyalty: how does job change relate to organizational commitment.Journal of Vocational Behavior, 65 (2), 332-49.

McQuail, D. (2000). McQuail's Mass Communication Theory. New Delhi: Sage Publications.

Meyer, J.P., Stanley, D.J., Herscovitch, L. \&Topolnytsky, L. (2002). Affective, continuance and normative commitment to the organisation: A meta-analysis of antecedents, correlates and consequences. Journal of Vocational Behavior, 61 (1), 20-52.

Meyer, J.P. \&Herscovitch, L. (2001). Commitment in the workplace: Toward a general model.Human Resource Management Review, 11 (3), 299-326.

Meyer, J.P. \& Allen, N.J. (1997). Commitment in the Workplace. San Francisco, CA: Sage Publications.

Pearce, D. (2003). The Social And Economic Value of Construction. London: The Construction Research and Innovation Strategy Panel (CRISP).

Pearce, J. L. (2007). Organizational behavior unchained. Journal of Organizational Behavior, 28(6), 811-814.

Pierce, C. M. B., \& Molloy, G. N. (1990). Psychological and biographical differences between secondary school teachers experiencing high and low levels of burnout. British Journal of Educational Psychology, 60, 3751.

Plasser, Fritz (2005). From Hard to Soft News Standards? How Political Journalists in Different Media Systems Evaluate the Shifting Quality of News, The Harvard International Journal of Press/Politics, 10 (2), 47-68.

Porters, W.L., Steers, R., Mowday, R., \&Boulian, P. (1974). Organizational commitment, job satisfaction and turnover among psychiatric technicians. Journal of Applied Psychology, 59 (9), 603-609.

Porter, L.W., Steers, R.M., Mowday, R.T., \&Boulian, P.V. (1974). Organizational commitment, job satisfaction, and turnover among psychiatric technicians. Journal of Applied Psychology, 59, 603-609.

Preston, P. (2009). Making the News: Journalism and News Cultures in Europe. London: Routledge.

Riketta, M., \& Van Dick, R. (2005). Foci of attachment in organizations: A meta analytic comparison of the strength and correlates of workgroup versus organizational identification and commitment. Journal of Vocational Behavior, 67(3), 490-510.

Rhoades, L., \& Eisenberger, R. (2002). Perceived organizational support: A review of the literature. Journal of Applied Psychology , 87 (4), 698-714.

Rhoades, L., Eisenberger, R., \& Armeli, S. (2001). Affective commitment to the organization: The contribution of perceived organizational support. Journal of Applied Psychology , 86 (5), 825-836.

Shoemaker, P., \& Reese, S. (1996). Mediating the Message in the 21st Century: A Media Sociology Perspective. New York: Longman.

Sinha, P. \& Sayeed, O.B. (1980). Measuring Quality of Working Life: Development of an Inventory. Indian Journal of Social Work, 41, 219-26.

Subramaniam, N., \& Mia, L. (2003). A note on work-related values, budget emphasis and managers' organisational commitment. Management Accounting Research, 14(4), 389408.

Tellefsen, T., \& Thomas, G. P. (2005). The antecedents and consequences of organizational and personal commitment in business service relationships. Industrial Marketing Management, 34(1), 23- 37.

Vadhera, N.M. (2014) Do Indian newspapers focus too much on crime stories? International Journal of Physical and Social Sciences, 4(7), 144.

Vadhera, N.M. (2014) Political news coverage on front page of Indian newspapers: an analysis, International Journal of Research in Social Sciences, 4 (2), 119-128.

Vadhera, N.M. (2015) What Ails the Indian Media Organizations? International Journal of Research in Social Sciences, 5(4), 104-112.

Vadhera, N.M. (2016) The Indian Media Organizations: Editors as Leaders, Media Asia, $43 \quad(1), \quad 49-55 . \quad$ DOI: 10.1080/01296612.2016.1170411

Vandenberghe, C., Bentein, K., \& Stinglhamber, F. (2004). Affective commitment to the organization, supervisor, and work group: Antecedents and outcomes. Journal of Vocational Behavior, 64 (1), 47-71.

Wiener, Y. (1982). Commitment in organizations: A normative view. The Academy of Management Review, 7 (3), 418-428. 